\title{
6 Postwar immigration and integration policies in the Netherlands
}

\author{
An unstable marriage
}

Rinus Penninx

\section{Introduction: studying the relationship between immigration and integration policies}

Immigration and the settlement of newcomers in the Netherlands have a long and rich history that has been well documented recently (Lucassen and Lucassen 2018; Lucassen and Penninx 1997; Obdeijn and Schrover 2008). The volume and patterns of immigration and emigration, however, have varied strongly, as has the reaction of Dutch society towards immigration and newcomers. Over quite a long period - roughly between 1580 and 1800, thus including the Dutch Golden Age - immigration into the Republic of the Seven United Provinces took place on a large scale. Most of these newcomers flocked to Dutch cities, where trade and industry flourished.

In contradistinction, in the next period - roughly between 1870 and $1960-$ more people left the Netherlands than came into the country. The country built up a tradition of emigration, particularly to North America, until the USA closed its borders in the early 1920s. This emigration tradition was picked up again after the end of World War II: civil society and the government (re)built an infrastructure to promote emigration to Canada, Australia, New Zealand, the USA and destinations in South America.

Postwar emigration fever receded in the 1960s and migrant workers arrived to fill the lowest ranks of the labour market of a booming economy, recovered from the war. From 1960 to the present, a period followed in which immigration was systematically more important than emigration (except for a few years - 1966/67 and 2002-2007 - with a small negative net migration).

\section{Key questions and how to study them}

It is against this historical background of the migration experience in the Netherlands that I focus on Dutch immigration and integration ${ }^{1}$ policies and how these have related to each other since the end of World War II in 1945. The key issues are:

- firstly, how Dutch society and the Dutch government looked at newcomers and decided who they wanted to admit; 
- $\quad$ secondly, how immigrants were assigned a place in Dutch society and how they were helped to find that place; and

- thirdly, how the ideas and practices concerning the admission of newcomers (i.e. immigration policies) were influenced or determined by those of assigning a place to newcomers (i.e. integration policies), or vice versa.

How to study immigration and integration policies? ${ }^{2}$ The essence of policies is the intention to guide and steer processes in society. Immigration and integration policies are part of a normative political process in which the issues of immigration and integration are formulated as problems; these problems are given a normative framing and concrete policy measures are designed and implemented to achieve the desired outcome.

In order to study immigration and integration policies empirically and their changes over time, I examine them on two levels. The first is the framing and aims of policies - i.e. looking at how the problem is actually defined and explained and at what can and should be done about it. Definition of the problem takes into consideration how immigration is perceived: is it seen as a problem, as an opportunity or as a necessity? Who has the moral or legal right to be or become an immigrant? Who are the wanted immigrants and who the unwanted ones? For those immigrants already present in the host society, a basic issue is whether they are seen as 'foreigners', as 'temporary guests' or as permanent members of society for whom the state accepts the same responsibilities as for native citizens, guaranteeing the same rights and providing the same facilities. To study these elements of framing, I refer to original policy documents and contemporary sources. ${ }^{3}$

The second level refers to the embodiment of policies in regulations, organisations, programmes and budgets. The study of these concrete aspects of policies allows a distinction to be made between symbolic and substantial policies and to measure the seriousness and possible selectiveness of policies in practice.

Such an analysis leads me to distinguish five periods in the postwar Netherlands in which migration and/or integration policies were defined differently and their practices changed. In the next section I describe migration and integration policies in these five periods and, for each period, ask how the relationship between migration and integration was framed.

\section{Emigration fever in an 'overpopulated' country and unsolicited newcomers, $1945-1960^{4}$}

In the postwar period, the Netherlands regarded itself as an 'overpopulated' country. It had the fastest demographic growth (and highest fertility) rate in Europe and an economy - destroyed by the war - that could not offer employment for its growing population. This 'population pressure' was to be combatted by a governmental policy designed to stimulate industrial development on the one hand and emigration on the other (Beijer and Oudegeest 1952). Emigration was encouraged and assisted by Emigration Boards in this pillarised Dutch society (a Catholic, a Protestant and a nonreligious Board) that revived their pre-1920s activities. 
Government policies saw emigration as part of the solution to unemployment and poverty. The government subsidised the Emigration Boards that prepared and assisted individuals and families to leave for a new home elsewhere. The general public's willingness to emigrate was so high that observers spoke of 'emigration fever'. Indeed, many left the country for Canada, Australia, New Zealand, the USA and destinations in South America. Between 1946 and 1969, about 450,000 Dutch emigrated -4.5 per cent of the population of 10 million (as of 1949).

Although the preceding paragraph makes it abundantly clear that the Netherlands did not see itself as an immigration country, this same period saw nearly as many people coming into the country as left it. These newcomers were not defined and seen as migrants or immigrants (this terminology was used later by researchers but did not fit in public discourse and policy frames at that time and was not used). The first large category to arrive in the Netherlands was that of repatriates from the Dutch East Indies/Indonesia and New Guinea. Their arrival was a consequence of the War of Independence (1945-1948) and the actual independence of Indonesia in 1948. In the period 1945 to 1962 , an estimated 300,000 people left Indonesia for the Netherlands. Some were white European settlers in the former Dutch colony. The majority, around 180,000, was of mixed Indonesian-Dutch descent, who were entitled to settle in the Netherlands due to their Dutch citizenship but were not encouraged to do so. ${ }^{5}$ The term 'repatriates' thus actually reflected their legal status: only those who could claim Dutch citizenship by recognised descent from a Dutch citizen were allowed to come to Patria (most had never been there before). Native Indonesians and even persons of mixed origin who had not been recognised as a descendant by a white parent, were not allowed to 'repatriate'.

The restrictive application of the right to 'repatriate' became very clear for Moluccan soldiers of the former colonial armed forces. ${ }^{6}$ After Indonesia gained its independence, part of the former colonial army was interned in a camp on the island of Java. Most were of Moluccan origin. They refused to demobilise on Java and instead wanted to go back to the Moluccas, to the independent Moluccan state that they had expected to be established there. However, the Indonesian government did not allow them to go there and the Dutch government did not want them taken to the Netherlands. After three years of imprisonment on Java, they finally won a court case against the Dutch government; the latter was obliged to bring its soldiers to the Netherlands: 12,500 persons - soldiers and their families - arrived there in 1951. Both the soldiers themselves and the Dutch government regarded their stay as temporary, as they intended to return to a Free Republic of the Moluccas (which, however, never came into existence).

What were the ideas and policies concerning these newcomers in Dutch society, who had arrived unsolicited and who were ostensibly not called immigrants? As for repatriates, it was clear that the Dutch government felt responsible for these citizens, for whom a place had to be found in Dutch society. There was a consensus between the government and the leaders of the different pillars to define 'repatriates as "Dutchmen in need" as the basis of the policy' (Amersfoort 1982: 96). So, an active reception (in contract pensions) and settlement policy 
was put in place, assistance in (re)schooling and finding work was provided and social assistance was organised in cooperation with pillared welfare organisations, including courses on how to manage a family business in the Netherlands a full-fledged assimilation policy. The mainly quick and smooth integration of the repatriates was helped by their relatively high educational level and strong orientation towards the Netherlands on the one hand and a quickly recovering and expanding economy and labour market in the 1950s on the other (Amersfoort 1982; Surie 1971).

How different were the ideas, policies and practices relating to the future place of Moluccans (at that time called Ambonezen) in Dutch society. The soldiers were formally dismissed from the army upon arrival in the Netherlands in 1951, thereby losing their status, work and income. Their stay in the Netherlands was seen as temporary and they were housed in isolated camps, mostly in rural areas. A special service - the 'Commissariaat Ambonezenzorg' - was created within the Ministry of Social Work to care for these temporary guests.

The educational level of the Moluccans was low and knowledge of the Dutch language virtually absent (Bartels 1989). These were unfavourable conditions for any kind of adjustment to Dutch society. Furthermore, the Moluccans themselves had the firm intention to return to an independent Moluccan state. Add to this a government policy that intended to keep the group intact with a view to return to the Moluccas. However, the desired return never materialised, which led to the long-lasting 'temporary' existence of an isolated group in exile under ambivalent governmental policies. It was only in 1978, after a series of violent occupations and hijackings by Moluccan youths in the mid-1970s, that the Dutch government's policy objectives were explicitly changed: the permanent residence of this group in Dutch society was to be accepted. Relations between Moluccans and the state were to be revised, rehabilitation for Moluccans would be provided and an active policy for the structural and socio-cultural emancipation of the group in Dutch society was proposed and accepted. The policy paper on the future of the Moluccans (Ministerie van Binnenlandse Zaken 1978) turned out to be the forerunner of the Ethnic Minorities Policy (Ministerie van Binnenlandse Zaken 1980, 1983).

\section{An 'unwilling immigration country' ${ }^{7}$ that needs (guest)workers: ${ }^{8}$ 1960-1980}

By the end of the 1950s, the country's postwar economic reconstruction was so successful that labour reserves decreased significantly and, in labour-intensive industries (metallurgy, food and textile industries and mining), it was difficult to find sufficient workers. Initially, foreign workers arrived 'spontaneously' or were directly recruited by employers but, from 1961, a state-organised official recruitment drive started to fill vacancies, mainly with un- or low-skilled workers. First came Italians, then Spaniards, Portuguese, Greeks and Yugoslavs; still later came Turks, Moroccans, Tunisians and Algerians. Between 1961 and 1975, some 85,000 migrant workers were officially recruited until the drive was ended 
in 1974. However, many more came. By 1975 there were about 170,000 legally resident citizens from the recruitment countries in the Netherlands, the great majority being workers.

The first oil crisis of 1973 led to the recruitment drive ending but this did not mean decreasing immigration. Immigration from Italy, Spain, Portugal, Greece and Yugoslavia halted and return migration for these groups was substantial. This, in combination with a significant naturalisation, led to a gradual decrease of these 'foreign populations' from the mid-1970s. However, the Turkish and North African workers reacted quite differently: where possible, these workers took their families to the Netherlands and, in five years, their population doubled to 121,000 Turks and 73,000 Moroccans by 1980 .

So how was this immigration of workers perceived and what policy frames can be recognised (Entzinger 1975; Penninx 1979)? Policy was dominated by the belief that foreign workers' engagement was only temporary - which is why they were popularly called 'gastarbeiders' (guestworkers). Initially (1960-1967) they were seen as a buffer for industrial sectors being restructured and for general fluctuations in economic activity. The government was willing to cooperate in satisfying industry's need for manpower, as long as the best interest of Dutch society (housing, public health, employment) was not in danger (Staay 1967, 1973). In the interests of efficiency and to avoid abuses, official recruitment agreements were drawn up with countries of origin. At the same time, the Ministry for Social Affairs and Employment set up a tripartite system for the approval for recruitment in which employers had to prove that no one was available on the labour market to fill the vacancies and trade unions had to give their consent.

The new Aliens Act of 1965 laid down a general legal framework that could be applied as flexibly or strictly as desired by means of Aliens' Regulations which could easily be amended - and of internal circulars laying down administrative guidelines. In this way, the Act could readily be applied in accordance with the demands of the labour market. Responsibility for foreigners' social welfare was devolved to the lower levels of government (Praag 1973), as was finding accommodation for them in the tight housing market. Private initiatives at local or regional levels were encouraged - especially those by churches (the initial migrants being Catholic Italians and Spaniards) - and Foreign Workers Assistance units were widely set up. By subsidising these units, the government was able to transfer important responsibilities to them.

As a result of the brief economic recession in 1966/7 - which did not cause a substantial return of guestworkers - the concept of the foreign worker acting as a buffer against fluctuations in economic activity receded but the temporary nature of 'guestwork' remained a basic policy premise. 'The Netherlands is not an immigration country' was the crucial sentence in the Memorandum on Foreign Workers of 1970, the first official document of the Ministry for Social Affairs and Employment on the subject (Ministerie van Sociale Zaken en Werkgelegenheid 1970). At the same time, there was a growing awareness that a significant number of foreign workers were staying for increasingly lengthy periods. The government answered by exclusively highlighting the part played by foreigners as buffers in 


\section{Rinus Penninx}

the restructuring of the Dutch economy. It maintained that 'guestwork' would become redundant when the restructuring process was complete. The concept of 'temporary employment during the restructuring process' had two logical implications for the government's policies. Firstly, there had to be greater control over immigration and employment and, secondly, the temporary nature of 'guestwork' should be stressed where possible.

Greater control over migration was exercised particularly through a workpermit policy. The Work Permits Act of 1969 ruled out spontaneous recruitment in principle while a tightening of residence-permit procedures led to the requirement for foreigners to obtain a temporary residence visa before being admitted to the Netherlands. Visas could only be applied for in the country of origin. During the boom years of recruitment (1969-1971), however, the stricter regulation of their admission proved to have little effect on the actual inflow of recruited workers. The increasing demand for labour made foreign workers indispensable until the economic crisis of 1973.

Encouraging the idea of temporariness in terms of policy instruments had long been nonexistent. The discussion did get an impulse from the General Employers' Association, which laid down a number of basic principles on temporariness and rotation in 1969 (AWV 1969). They proposed a selective and limited employment of a non-permanent nature for individual foreigners; their stay would be restricted to two or three years. A rotation system would prevent the permanent settlement of foreigners, while employers would be able to recruit fresh labour. The costs associated with such matters as family reunification and the integration of foreign children would then be avoided. Similar ideas were sounded out by policy-makers at a somewhat later stage which, in 1972, led to the expectation that a two-year regulation would be proposed by the government. However, resistance to policies of this kind was so great that these proposals were not even tabled in parliament.

The period between the 1970 Memorandum on Foreign Workers as a draft policy document of the Ministry for Social Affairs and Employment and its finalisation as a policy document in 1974 (Ministerie van Sociale Zaken en Werkgelegenheid 1974) was a turbulent period in several ways. Firstly, the years 1970 and 1971 were the absolute peak years of recruitment, followed by a period of recession and the first oil crisis of 1973 and the factual halt of the recruitment drive in 1974. Secondly, the societal debate on guestworkers was broadened. One important criticism was directed particularly towards the narrowly nationalistic, one-sided economic character of the Memorandum of 1970 and the absence of any reference to a migration-for-development perspective for countries of origin. Another complaint voiced by welfare organisations was that too little attention was paid to the social consequences of labour immigration in the Netherlands. Finally, in the period between the draft Memorandum of 1970 and the final document of 1974, a new centre-left coalition led by the Labour Party had replaced the coalition of religious parties.

The Memorandum of Reply in 1974 (Ministerie van Sociale Zaken en Werkgelegenheid 1974) by the Den Uyl Cabinet was a new policy document in that it introduced fresh topics such as the relationship between labour migration and 
economic development in the countries of origin and the long-term economic and social consequences of labour migration in the Netherlands, as well as concrete policy areas such as housing and education. There was more balance in the sense that more facets of the problem were explored and more ministries had been involved in the writing of this final document. At the same time, nevertheless, it is fair to conclude that there was little substantive change in the basic premises underlying policy: the Netherlands was not an immigration country and the employment of foreign workers was therefore a temporary phenomenon. Increasing recognition was given to the fact that foreign workers tended to be employed in certain types of work - i.e. poorly paid and generally unpleasant and heavy work. Despite this recognition, however, the Memorandum of Reply continued to maintain that foreign workers could be dispensed with in the long run: it referred to the need for 'specific labour-saving' investments in order to do away with the need for unskilled labour.

As a follow-up to earlier discussions about a possible two-year regulation, the Memorandum of Reply proposed the payment of a return premium (reference being made to a sum of 5,000 guilders, i.e. some 2,273 euros) to every foreigner who had worked in the Netherlands for two or three years, in order to encourage their remigration and the rotation principle. Such a departure premium would also have the policy advantage of clearly distinguishing 'temporary' from 'longstanding' migrants. This proposal - which soon became popularly known as the 'rot-op-premie' (piss-off premium) - came in for sharp criticism and its implementation proved politically unfeasible.

In November 1975, in another effort to control the immigration of workers, the Minister of Social Affairs submitted a proposal for a law titled 'Provisions governing the employment of foreign workers' (Foreign Workers Act, TK 1975-1976 13 $682,1-4)$. The proposal obliged an employer to obtain an employment permit valid only for the named foreigner - before he could engage a foreign worker. This made the latter tied to and dependent on 'his' employer. Furthermore, the bill envisaged the imposition of limits by the government on the number of foreigners who could be employed by a company. The new law would mean that, after a foreigner's contract had expired, work could only be obtained with employers who had fewer foreigners on their staff than their limit.

The proposal met with strong resistance by employers, trade unions and lawyers, although an amended version was, nevertheless, approved by the Lower House in 1976. The most significant change by amendment was that foreigners who had worked in the Netherlands legally for three years (as opposed to the original five) would fall outside the scope of the Act. Given the small number of foreign workers who would currently be subject to the Act, the bill became an impotent instrument. Use could, however, be made of the legislation if recruitment were to be resumed. The law came into force in 1979 - more than five years after the classical guestworker period had ended.

From the foregoing it is clear that guestworkers were the category that dominated migration flows and policies in the period 1960-1980 though they were not the only newcomers in that period. Colonial immigration from Suriname ${ }^{9}$ was an 
important second category of newcomers who - like the repatriates before - were not seen as immigrants. Until its independence in 1975, Suriname was part of the Dutch Kingdom. The inhabitants of Suriname were called 'Overzeese Rijksgenoten' (overseas fellow countrymen); they were Dutch citizens and migration was free. Immigration from Suriname to the continental Kingdom of the Netherlands gained some weight in the 1960s (partly as a consequence of the recruitment of workers) but became significant in the years before the independence of Suriname (1973-1975). The country's independence in November 1975 would mean that those who were there would in principle get Surinamese nationality and would fall under the immigration regime for foreigners in the Netherlands. ${ }^{10}$ This was an important reason for many to move to the Netherlands before November 1975. In 1975 alone, some 40,000 moved to the Netherlands, followed by a second wave in 1979-1980, prior to the expiration of the transitional agreement on the settlement of mutual subjects (for five years after Suriname's independence, its inhabitants could opt for Dutch nationality). By 1980, the population of Surinamese origin in the Netherlands was about 180,000 .

As for reception and integration policies for Surinamese in the 1970s, there was a strong resemblance with those for repatriates from the Dutch Indies, which were about receiving fellow citizens in the mother country. The Ministry of Culture, Recreation and Social Work (formerly just Social Work) coordinated a housing policy of dispersal (to relieve the big cities) and special measures for integration in the labour market and education.

\section{Accepting immigrant minorities in a nonimmigration country: ethnic-minorities policy 1980-1994}

In the 1970s, when sizeable immigration from Suriname took place and the Mediterranean guestworker populations grew quickly through family immigration, the 'tension between norm (that the Netherlands should not be an immigration country) and fact (that there were significant immigrant populations)' increased (Entzinger 1975: 327). The 'fiction of temporary stay' was deeply ingrained in admission policies, in laws and regulations governing the legal position of (alien) immigrants and in reception policies. Reception facilities were meagre and organised for certain groups of immigrants, apart from the regular social services. The Netherlands was not only an immigration country against its will (Entzinger 1985: 67), it was also an 'unwilling immigration country' (Amersfoort and Surie 1987; Groenendijk 1981).

At the end of the 1970s the political discussion on immigrants changed. The hijackings of trains and the occupations of buildings by groups of young Moluccans in the mid-1970s had a dramatic impact on Dutch society but also triggered a new policy vision: the fiction of temporality was declared outdated and the future of this group within Dutch society became a central topic in a new policy document on Moluccans in 1978 (Ministerie van Binnenlandse Zaken 1978). The report Ethnic Minorities by the Scientific Council for Government Policy (1979) formed the impetus for politics to apply the same kind of reasoning for other 
immigrant groups. This led to the announcement of a new 'overall ethnic minorities policy' in 1980, the Draft Minorities Bill in 1981 and the final Minorities Bill in 1983 (Ministerie van Binnenlandse Zaken 1980, 1981, 1983). It is important to underline here that the changes did not relate to immigration policies: these should be restrictive, as before. The change related to integration and the position of vulnerable groups in Dutch society - (immigrant and other) groups with a low socio-economic status who were seen as socio-culturally different from the mainstream and in danger of permanent marginalisation. These groups should emancipate in the socio-economic and socio-cultural sense. It was not a policy for all immigrant groups and not all target groups of ethnic-minorities policy (EMP), such as Dutch caravan dwellers, were immigrants. The most important change for immigrant groups was that policy should be based on the expectation that current immigrants would be permanent residents in Dutch society.

In the new EMP documents, two main aims were formulated. On the one hand a tolerant, multicultural or multi-ethnic society should be created in which cultural and ethnic difference would be accepted and appreciated and ethno-cultural groups could emancipate. On the other hand, EMP was a policy of socio-economic equality: it aimed at solving the arrears of minorities' social position in Dutch society and fighting the (institutional) discrimination which leads to unequal chances and sustains these arrears.

The first aim demanded by its very nature group-specific measures but, in the new policy, this was done from the perspective of the fundamental rights of these groups in and as part of an envisaged multicultural Dutch society. Organisations of immigrants themselves were given important tasks in 'maintaining and developing their own culture and identity'. As to the content of this maintenance and the development of culture and identity, governmental agencies should not intervene but, rather, keep their distance. The main task of these agencies and their policies was to remove barriers and fight intolerance of the society or of certain groups. ${ }^{11}$

To realise the second aim it was stipulated that a consistent policy of fighting arrears and promoting equal opportunities should be applied within the general policies applicable to the domains of labour market, education and housing. The accessibility of facilities and institutions, non-discriminatory treatment and equal opportunities were the key words. In governmental facilities and institutions, the new key term 'proportional representation or share' was introduced in the $1980 \mathrm{~s}$ as a yardstick of good functioning in relation to immigrants.

The Dutch government intended to specify these general aims in a number of domains: the improvement of the social position of immigrants should be traceable in the fields of labour and income, education and housing. As to the first domain, the policy included improvement of the service of Employment Exchanges for immigrants; stimulating the participation of immigrants in training and (re-)schooling programmes; realising the proportional participation of immigrants in 'job placement' and 'employment' programmes; removing obstacles for small entrepreneurs among immigrants and providing (information) services for them; and, finally, opening up employment opportunities for immigrants within governmental services by removing formal (legal) hindrances and by striving for 
the proportional representation of minority groups among government employees (including affirmative action programmes since 1986). For the private market, a softer legislation, the 'Employment Equity Act', borrowed from Canada, was discussed for quite some time and was finally introduced in 1994.

EMP also invested strongly in educational policies for minorities. The two goals of this plan were equal educational opportunities and the equivalence of cultures. The first goal was to be achieved by putting more emphasis on Dutch language-teaching and by intensifying contacts between immigrant parents and their children's schools. To enable them to provide such extra and special instruction in the Dutch language, extra facilities were given to schools, depending on the number of immigrant pupils, their duration of stay and their country of origin. It was particularly assumed that pupils from non-Dutch-speaking backgrounds needed extra lessons in Dutch during the first two years of their stay. The second goal, the equivalence of culture, would be achieved through two different provisions: Education in Mother-tongue and Culture (EMC) and Intercultural Education (IE). EMC teaching was set up in the Netherlands in the early 1970s to facilitate the eventual reintegration of pupils in the society of origin. In the 1980 policy plan, the goals of mother-tongue teaching were reformulated in psychological terms (Eldering 1989: 120): fostering the well-being and the ethnic awareness of children and guarding them against alienation from their parents and family, strengthening their identity etc. It was intended to contribute (indirectly) to greater achievements by these children. Intercultural Education should prepare the children of both ethnic/cultural groups and the indigenous Dutch majority to live together harmoniously in a multicultural society.

With regard to housing, the most important task, developed from the beginning of the 1980s, was to open up the market for rented family accommodation for immigrants on the same footing as for native-Dutch candidates. Regulations for application, urgency rules and distribution were made 'neutral' for immigrants and discriminatory rules were outlawed. These policies were the most successful in that part of the market owned by municipalities and housing corporations (which was quite sizeable in the large cities in the Netherlands).

In the Minorities Bill (Ministerie van Binnenlandse Zaken 1983: $107 \mathrm{ff}$ ) a multicultural society was envisaged in which immigrants would have the same rights and opportunities to practice and develop their own cultural and religious identity as other groups in Dutch society. Immigrants should be given room to develop their identity; Dutch society and its authorities should be open to these developments and adapt to the situation of a multicultural society.

As for the right to maintain and practice their culture, religion and language and to organise themselves as groups, immigrants were not been confronted with too many problems. The religiously 'pillared' and compartmentalised Dutch society had long recognised such fundamental rights, provided that the immigrants' cultural or religious norms, values and practices were not incompatible with the 'fundamental norms of our pluriform society' (Ministerie van Binnenlandse Zaken 1983: $107 \mathrm{ff})$. The existing facilities were available for the newcomers on the same conditions as for settled Dutch (religious, cultural or language) groups. 
As for the opportunities, however, policy-makers were realistic enough to see that these newcomers would not be able to make use of these rights on an equal footing, because of their small number, their low social position, low level of education and weak degree of organisation, which is why special efforts were made, such as:

a) strengthening immigrant or ethnic organisations by subsidising these at the local level and umbrella organisations at the national level;

b) stimulating the participation of immigrant organisations in the formation of policy through a National Consultative Council (Landelijk Overleg en Inspraakorgaan) that had sub-councils for each of the different immigrant groups;

c) facilitating religious activities for 'new' religions like Islam, Hinduism and Buddhism: religious chaplains in the army, prisons and hospitals were subsidised; there were religious instruction (IR) teachers in public schools and subsidies for houses of prayer (the latter were the first to be cut, after 1986); and

d) adapting laws and regulations to facilitate particular religious practices, such as ritual slaughtering and burials according to Hindu and Islamic rites. The public call for prayer of the Imam was formally accepted on the same footing as church bell-ringing in Christian churches.

An important element of EMP for non-Dutch citizens was also a policy of strengthening their legal position. The first aspect of this referred to security of residence. A permanent permit was to be extended after five years of continuous residence in the Netherlands and, for family members, after three years. Revocation or withdrawal of a permanent permit and its subsequent expatriation was only possible in very exceptional circumstances, like long-term prison sentences. Long-term unemployment and a dependency on social security benefits were insufficient grounds for revocation.

The second aspect concerned the equal treatment of legal immigrants and the native Dutch. An inventory was made of articles and phrases in Dutch laws and regulations in which discrimination according to nationality, religion, culture and language was made (Beune and Hessels 1983). Many of these articles were thus changed or deleted.

A third way to ameliorate the juridical position of aliens (and particularly their children) was a change in the law on Dutch citizenship and procedures of naturalisation. On 1 January 1985, a new law was introduced that made it much easier for the non-Dutch spouses of Dutch nationals and for third-generation children (born to parents who, themselves, were born in the Netherlands) to become Dutch citizens. An option was made available for aliens - born in the Netherlands and reaching their majority (at the age of 18) - to become Dutch citizens. Furthermore, government policy relating to dual nationality changed: the requirement that the former nationality should be rejected was dropped in many cases. These changes led to a steep rise in naturalisations (and dual-nationality cases) in the late 1980 and 1990s. 
Fourthly, aliens residing legally in the Netherlands for more than three years gained voting rights at municipal elections - implemented for the first time in 1986.

Lastly, another important element of the new minorities policies was the fight against discrimination. A number of amendments in laws were introduced to anchor the non-discrimination principle in Dutch law and to give more possibilities to prosecute discriminating persons and organisations. In Article 1 of the Constitutional Law, a new non-discrimination article was introduced forbidding, inter alia, discrimination according to race or religion. Some articles in the Penal Code were also adapted to facilitate the pursuit of discriminatory practices. Certain provisions in the Civil Code proved useful, too, in fighting discriminatory practices. It was also deemed necessary to make juridical procedures for complaints easier. Police and prosecutors were given instructions on how to deal effectively with cases of discrimination and the government subsidised a National Bureau for Combatting Racism which worked together with local anti-racist registration and service groups. Anti-discrimination training for government and municipal employees was introduced, and Intercultural Education facilities were created in schools.

The EMP, as outlined earlier, was not only comprehensive in its content and in the number of ministries and governmental agencies involved but was also organised differently. Where, in the past, it had been the Ministry for Social Work/ CRM that was made responsible for the reception and integration of repatriates, Moluccans and Surinamese, and the Ministry for Social Affairs and Employment had made policies for guestworkers, it was now the Ministry of the Interior that was made responsible for the coordination of EMP and that received a significant special budget to build and implement the new policies. This coordination related not only to the horizontal alignment of the various activities of ministries but also to the vertical alignment of policies with cities and municipalities, including the funding of research relevant for the development and evaluation of EMP.

We saw at the beginning of this section that the complete reframing of integration policies in EMP did not imply changes in the perception of immigration. On the contrary, 'the government's policy aims to prevent immigration as much as possible without violating national and international obligations. This means that family reunion and the admission of political refugees will be kept outside the restrictive policy' (Ministerie van Binnenlandse Zaken 1980: 21-22). So how did this work out in practice in this period?

Indeed, the period 1980-1994 was one of relatively lower overall immigration compared to the preceding decades. In terms of policies, however, we should distinguish three main categories: immigrant workers, the family members of immigrants and refugees and asylum-seekers.

For migrant workers, we have seen that the Foreign Workers Act was introduced in 1979 in order to control and channel labour migration. In the new economic context of the 1980s, characterised by a loss of employment in industry and the expansion of the service sector, these policies were meant to restrict the entrance of low-skilled foreign workers while facilitating the immigration of the 
highly skilled (who often came from extremely industrialised countries (Böcker and Clermonts 1995). By the end of the 1980s, persistent labour shortages in particular economic sectors forced the Dutch government to deal with the demand for foreign labour in a more structured fashion. As a consequence, the Dutch Employment Organisation, together with trade unions and employers, started to manage temporary labour migration through so-called 'covenants'. These tripartite agreements permitted workers in particular economic sectors to be temporarily admitted into the country while also anticipating the availability of newly trained, qualified Dutch workers. Contrary to what might be expected, however, these agreements did not always lead to a more liberal admission policy (Lange 2004). In any case, this type of labour immigration formed a negligible part of the total immigration in this period.

The new EMP, however, had initially positive consequences for the immigration of family members (particularly of guestworkers). EMP accepted the permanency of immigrants' stay as a starting point for integration policies. In principle, this new approach made the family part of the integration process. In practice, too, family reunification (i.e. the bringing over of the spouses and children of resident foreigners) thus went unquestioned and peaked in the early 1980s. When the Ministry of Justice decided to introduce restrictions on family formation (i.e. bringing over new marriage partners), there was fierce resistance from political parties, which argued that the measure undermined the principle of equal treatment at the heart of the new minorities policy. In this regard, liberal family migration policies were part and parcel of EMP.

Refugee and asylum policies in the Netherlands have been developed, mainly ad hoc, following the increase in asylum-seekers during the 1980s and 1990s. From 1977 to 1987 , annual quotas were established to determine the number of refugees invited to resettle in the Netherlands. However, the growing numbers of spontaneous asylum-seekers, a housing shortage and the increased costs that municipalities had to pay for social and other benefits, led to the introduction of the Regulation on the Reception of Asylum-Seekers (ROA) in 1987. The first aim of the ROA was to curtail asylum-seekers' access to independent housing and social benefits and, instead, to offer them central reception and modest sums of pocket money. Muus (1997) observed that the ROA, described as 'austere but humane', was instated not only to relieve the growing housing and financial problems of the major cities but also - and above all - to prevent the Netherlands from becoming an attractive destination country. This shift made evident how reception policies were, both in fact and in perception, a significant component in the management of asylum flows.

Due to the growing number of newly arriving asylum-seekers from 1989 onwards, the ROA became a policy of providing minimal first accommodation; yet within just a few years, it became overburdened. In 1990, for example, the Ministry of Welfare, Health and Culture, in charge of the reception of asylum-seekers, 'tried to solve the problem by means of buying or renting holiday bungalows and caravans and finding more municipalities that were prepared to accommodate asylum-seekers' (Muus 1990: 47). In 1992, the New Admission and Reception 
Model for Asylum-Seekers (NTOM) was introduced. Under this system, reception centres were the responsibility of the ROA; municipalities would henceforth only bear responsibility for the reception and integration of those who had passed asylum procedures - namely status-holders and the gedoogden (persons with a temporary expulsion waiver). Moreover, in the early 1990s, the Ministry of Justice introduced several measures to reduce the number of asylum requests. First and foremost, measures were taken to prevent asylum-seekers from even arriving in the Netherlands by increasing the number of countries whose citizens needed a visa. Secondly, in 1994 a temporary status - referred to as a Conditional Residence Permit (VVTV) - was introduced. This new status only carried with it a relatively weak provisional residence title and provided barely any access to public facilities. Thirdly, in 1994, like other countries, the Netherlands introduced procedures to expedite certain asylum applications such as 'manifestly unfounded applications' - those that were filed by people coming from safe countries of origin or safe transit countries where they could have applied for asylum. What is more, people who had applied elsewhere were excluded.

Notwithstanding these restrictive measures, the number of asylum-seekers did grow significantly, both absolutely and as part of total immigration, particularly in the beginning of the 1990s. In 1994, a peak of 52,600 asylum applications was registered in the Netherlands.

\section{Restrictive immigration and neoliberal 'citizenship policies' of integration: 1994-2002}

Already, in the late 1980s, discontent about EMP was growing. The first strong critique was formulated in a new report by the Scientific Council for Government Policy (1989), the same institute that had promoted EMP ten years earlier. The report's message was that too little progress had been made by EMP in the crucial domains of the labour market and education and too much attention was being given to issues of multiculturalism and (financial and other) support to ethnic organisations and to cultural aspects. It was suggested that the group approach and the prominence of cultural aspects in the policy had hindered - rather than enhanced - individual participation and the use of opportunities in the labour market and education. The advice of the Scientific Council for Government Policy (1989: 99) was thus to make more efforts in the key areas of labour and education and to do so with more compulsory measures. The message was that obligations of migrants should be more balanced with the extended rights and policies should focus less on cultural rights and facilities.

Other elements of criticism were later added. For one, Frits Bolkestein (1991), the then Liberal Party leader and head of the political opposition in the Dutch parliament, suggested in a public speech in 1991 that Islam formed a threat to liberal democracy. He also intimated that Islam was a hindrance to the integration of immigrants and that immigrant integration should be handled 'with more courage'. 
Policy did not change immediately in response to the critiques but the seeds for a different framing of integration were sown, to grow later. The distinct change in policy focus was found in the policy document Contourennota (Ministerie van Binnenlandse Zaken 1994). In this document a renewed integration policy was adopted, of which the keywords were 'good citizenship' and 'self-responsibility'. It argued that citizenship entails not only rights but also duties and that each citizen must be active and responsible for him- or herself. In accordance with the advice of the 1989 report of the Scientific Council for Government Policy, this new 'integration policy' confirmed three main deviations from EMP: a shift away from target groups to individuals who are in a disadvantaged position, a strong focus on socio-economic incorporation through labour market and education measures and a shift away from cultural and multicultural policies as well as from recognition and support for immigrant organisations.

The social-democrat victory in the national elections of 1994 led to the socalled Purple Coalition: the Labour Party (PvdA) together with the conservative liberals (VVD) and left-wing liberals (D66). The focus on the economic integration of individual immigrants recommended by the 1989 Scientific Council report fitted very well in the general policy line of the government, whose motto was 'work, work and, once again, work'. In this general approach, measures specifically targeted at migrants or ethnic minorities were abandoned.

A new policy instrument that fitted well in the new philosophy was that of civic integration courses. ${ }^{12}$ This instrument was developed at the local level in a number of Dutch cities in the early 1990s. On these reception courses, newcomers were given a toolkit consisting of Dutch-language training and information about the functioning of important institutions in Dutch society. Local policy-makers felt the urge to provide such a toolkit to all newcomers who needed it. This locally developed instrument for integration was taken over by national authorities in the second half of the 1990s and developed as a national reception policy in the 1998 WIN Law (Wet Inburgering Nederland or Law on Civic Integration).

Another way of transforming policies was by framing many of the integration facilities in area-based (rather than group-based) policies. In 1994, the Ministry of Home Affairs began to formulate a policy for 'deprived areas' in major Dutch cities. Ethnic-minority populations were strongly represented in these areas and holistic programmes that integrated measures on housing, economic issues and socio-cultural dimensions were developed. This policy was referred to as the Grotestedenbeleid (Urban Policy) from 1994 on. In 1998, a new Minister for Urban Policies and Integration (within the Ministry of Home Affairs) was made responsible for integration policies.

Finally, the new ideas of 'good citizenship' and 'self-responsibility' were not only expressed in the mandatory integration courses but also in the change of naturalisation policies in the second half of the 1990s. The lenient naturalisation practices under EMP that accepted dual nationality (and had transformed a large majority of foreign immigrants of the 1960s to 1990s into Dutch citizens) were inverted: naturalisation was reframed as the final result 
of an integration (inburgering) trajectory to be earned by immigrants and dual nationality was no longer to be accepted. The formal confirmation of this process of reframing the relation between migration, integration and naturalisation took place in the next phase of hyper-policisation: the New Nationality Law of 2003 re-introduced the requirement to give up a former nationality, introduced strict tests on knowledge of the Dutch language and society and strongly promoted the symbolic and ceremonial value of naturalisation. It thus formed one of the building stones of the Ministerie van Justitie's Integration Policy New Style of 2003.

When it came to immigration policies, the framing (of restrictiveness) did not essentially alter much in the period 1994 to 2003. However, there were two important changes to note. The first related to family migration. The shift in the framing of integration policy from a group-oriented approach to one focusing on individual integration caused a turn away from the principles of protecting family unity. Family migration started to be seen as a problem for the integration of individuals. As presented in the media and stated in many public debates, a broad majority within parliament believed that, due to a lack of knowledge and skills, those newcomers who immigrated in the framework of family formation or reunification would, if not fail to integrate, at least delay the integration process. This reasoning justified restrictive family migration policies (Walsum 2004). As a consequence, in the 1990s and 2000s, more-restrictive family migration measures were introduced with little debate.

The second change related to practices of policies to reduce irregular immigration from the early 1990s. The Linkage Law proposal was intended to make not only all social security benefits but also rights and access to secondary or higher education, housing, rent subsidy, handicapped facilities and health care for an immigrant contingent on his or her legal residence status. Practitioners in these fields were supposed to check legal residence before serving foreign clients. Driving this act was the assumption that an exclusion of access to public services would help to discourage irregular migration. The Linkage Act proposal generated widespread protest from doctors, teachers, legal experts, prominent politicians and representatives from a broad range of public, semi-private and private organisations. Representatives of local governments also campaigned against the law and seemed to steer a course towards non-enforcement. In general terms, the new law was claimed to be unnecessary, immoral and unworkable. This opposition produced a number of substantial alterations to the proposed bill. For instance, professionals were not forced to report irregular immigrants to the Aliens Department, restrictions concerning education for children were lifted and, whereas irregular immigrants would initially have only been entitled to medical care in 'acute and threatening situations', this specification was eventually superseded by the prospect of requiring 'imperative medical treatment'. The Linkage Law (Koppelingswet) came into force in 1998. It was presented as the centrepiece of an 'integrated immigration policy' (Pluymen 2004: 76). 


\section{Hyper-politicisation: socio-cultural integration demands as a condition for (restrictive and selective) immigration: 2002-2018}

A series of events around the turn of the millennium triggered a new shift in the public and political discourse on immigration and integration issues that would lead later to a revision of policy towards assimilationism (Vasta 2006). The social and the cultural dimensions of integration were even more central than before and were viewed through the normative lens of what were supposed to be Dutch norms and values. The search was no longer for 'compatibilities', but for 'commonalities' that would help to preserve national norms and values, thereby restoring and enhancing the social cohesion of society (Entzinger 2003). One of the initial catalysts in this new framing of immigration and integration was a newspaper article by Scheffer (2000) that spurred a new national debate. The article stated that multicultural society in the Netherlands could be dismissed as either a 'tragedy' or a 'disaster'. ${ }^{13}$ Integration policy was declared a failure; moreover, a call was made for a more assimilationist policy that would revive Dutch history, norms and values. Islam and the integration of Muslim immigrants were identified as being especially problematic.

At the same time, Dutch politics witnessed the rise of Pim Fortuyn, a populist politician who profiled himself through harsh statements on criminality, direct democracy, immigration and integration. He pleaded for 'zero migration', argued that 'the Netherlands was full' and called for 'a cold war against Islam'. ${ }^{14}$ To these arguments - which were not completely new - he added two elements: the accusation that the political elite had enabled the failure of integration in the past by 'hiding the real problems behind a curtain of political correct speech' and the contention that the victim of all this was the common - and, at that, native - Dutch voter.

Fortuyn's populist campaign exploited this discourse very successfully. His party won a great victory in the March 2002 local elections in Rotterdam, the Netherlands' second largest city. Only a few weeks later, Fortuyn was murdered just before the national elections of May 2002 in which the newly established LPF party (Lijst Pim Fortuyn) won a landslide victory, winning 26 of the 150 parliamentary seats and thus entering parliament as second largest party. This success radically changed political discourse on immigration and integration; other parties adapted their ways of speaking about the issues (Penninx 2006).

Another sequence of notable events followed. Firstly, a series of violent acts committed by immigrants drew wide media attention. Secondly, several events emerged around the issues of so-called fundamentalist mosques and radical Imams. Finally, a major climax came when the Dutch filmmaker Theo van Gogh was murdered by a Dutch-Moroccan youngster who was affiliated with a radical Islamist network in the Netherlands.

These events had two significant effects. First, they contributed to the image of failure of the country's integration policy. Parliament thus established a 
Parliamentary Inquiry Committee on the Integration Policy, made up of MPs from all parties in parliament, in order to examine 'why policy had thus far resulted in such limited successes'. When the Committee concluded that integration had actually been relatively successful (Blok Commission 2004), this judgement was widely dismissed as naïve. A new political correctness seemed to have emerged that would taboo positive statements on integration policy and on multiculturalism. ${ }^{15}$ Secondly, these events reinforced a new mode of policy discourse, described by Prins (2002) as 'hyperrealism' - a shift from the 1990s 'realist' style of discourse demanding a 'tough' approach to integration that should turn immigrants into full citizens, to a type of discourse in which 'being tough' became a goal in itself, regardless of its potentially problematic effects.

Thus, from 2002 onwards, a new policy and a new policy style became visible. The first element of this shift was the renewed institutional embedding of policies in the first Balkenende Cabinet in 2002: integration policies were moved from the Ministry of Home Affairs (in which they had been located since 1980, the beginning of EMP) to the Ministry of Justice, under a new special Minister for Aliens' Affairs and Integration. It signaled the subordination of integration to immigration policies. ${ }^{16}$ The new Integration Policy New Style, formulated in a letter by the new minister (Ministerie van Justitie 2003), continued to follow the leading concepts of 'citizenship' and 'self-responsibility' of the $1990 \mathrm{~s}^{17}$ but the emphasis had shifted strongly from the socio-economic aspects of integration to the cultural adaptation of immigrants to Dutch society. Integration policy was thus narrowed considerably, mainly down to civic integration courses.

These courses - and the WIN Law of 1998 - had to be transformed into 'a new style', according to Minister Rita Verdonk. ${ }^{18}$ To begin with, civic integration courses were not only mandatory but also had to be passed within a certain period (three and a half years); passing was a condition for the obtention of a permanent residence permit (and, for asylum-seekers, a definitive residence permit (after a temporary one). In the implementation of these courses, a new distribution of responsibilities among their stakeholders was proposed (and formalised in the new WIN Law that came into force in 2007). Firstly, the migrant coming to the Netherlands was expected to find and fund the course him- or herself. Only if s/he eventually passed the exam would s/he be entitled to a refund of up to 70 per cent of the cost of the course. Secondly, the responsibilities of local authorities were changed: although they still had to monitor newcomers and their efforts to follow courses, the authorities' organisational and financial resources to promote such a process were minimised. Thirdly, civic integration courses were to be privatised: while, since 1998, a nationwide network of state-sponsored Regional Educational Centres (ROCs) had developed which offered civic integration courses, now anyone could offer such programmes. This led to the rapid dissolution of the existing infrastructure of ROCs and to a market with many low-quality and inexperienced new educators - and to a chaotic field for the migrant, who had to make this choice him- or herself (see evaluations done in subsequent years: Algemene Rekenkamer 2017; Significant 2010). 
The Minister for Alien Affairs and Integration, Rita Verdonk, also tried to expand the target population of the new reception policy: civic integration courses should be mandatory for all immigrants between the ages of 16 and 65, regardless of the amount of time they had spent in the Netherlands and of whether they were foreigners or naturalised Dutch. However, the Minister lost this battle on legal grounds. From the final version of the law that was ultimately passed at the very end of the cabinet's legislative term, in July 2006, the obligation to follow and pass civic integration courses was removed for Dutch citizens - native or naturalised.

The star measure in this new policy was the WIB Law (Law on Civic Integration Courses Abroad) of 2006, which introduced a pre-migration test for new migrants who wanted to move to the Netherlands, particularly family migrants. Since 2006, newcomers have to pass an exam in their country of origin that proves their Dutch language skills and basic knowledge of Dutch culture and society before a provisional visa to enter the Netherlands is given. Once admitted to the Netherlands, migrants must attend - and successfully complete - civic integration courses in order to be granted both temporary and permanent permit renewals. In this law, integration policy had become clearly linked, instrumental even, to immigration policy. It facilitated the selection of migrants and restricted new flows, particularly those of family reunion and marriage migration.

The four years of this New Style policy were different not only in content but also, markedly, in the style of policy-making and implementation. The process of policy-making - in a strongly politicised context - was predominantly led by the Minister and political parties in parliament. At the same time, this policy-making was very selective in the topics it chose: in the first place, as we have seen, mandatory civic integration courses, both before arrival and after, as well as the restrictive admission of new immigrants and forced return of failed asylum-seekers and illegal immigrants.

As for immigration policy, the (very restrictive) policy of the New Style was, firstly, visible in the additional conditions for immigration described earlier: the mandatory tests that (certain categories of) aspiring immigrants had to pass before they would receive their first provisional visa to enter the Netherlands and the strongly increased costs, for aspiring immigrants, of visas, (temporary) permits and mandatory courses. Secondly, there was the stricter application of policies set earlier. In this latter category fall, among other things, implementation of the Linkage Act (combatting illegal residence) and the application of asylum procedures and return policy for refused asylum-seekers and other irregular migrants.

As for labour migration, restrictive policies continued, expressed, in this period, the most concretely in the postponement of free access to the labour market for the citizens of the new EU accessor states from Central and Eastern Europe in 2004 and 2007: a transitional period of five years was established in which, for example, Poles, Romanians and Bulgarians could freely move to the Netherlands but still needed a work permit to take up a regular job. 
As for family migration, the discourse introduced in the 1990s that family migration was a potential threat for integration became more dominant than ever before - the WIB Law of 2006, which required the pre-migration examination of the non-Dutch family members of residents who wanted to immigrate, was the embodiment of this discourse.

As for asylum migration policies, two sets of measures were relevant in this phase. In the first place, measures continued to be taken which aimed to reduce the number of asylum applications and the duration of asylum procedures. These measures were taken so far that they aroused concerns not only from refugee advocacy groups and academics within the Netherlands but also from the United Nations High Commissioner for Refugees (UNHCR) and Human Rights Watch (HRW). Secondly, there was the problematic non-return of failed asylum-seekers to their country of origin. In February 2004, the Minister for Immigration and Integration proposed to expel up to 26,000 'failed asylum-seekers' over the following three years - a proposal that was accepted by the Dutch parliament but which also generated the opposition of local authorities and grassroots organisations.

The strong anti-immigration climate and the concrete restrictive measures were obviously effective during the Balkenende I, II and III Cabinets (2002-2007): all four immigration categories (labour, study, asylum and family immigration) decreased compared to the previous period. For the years 2003-2006, a negative net migration (more people left the country than arrived) was registered for the first time since the 1960s (it turned out to be temporary, as we will see later).

I have been somewhat elaborate here about what happened to immigration and integration policies between 2002 and 2007 because a new framing was established in which immigration and integration policies became linked in a special way and a structure was created of pre- and post-migration civic integration courses of an assimilative nature. This framing and this structure were embodied in the new Wet Inburgering 2007 (Law on Civic Integration) which was essentially maintained later, in its revisions in 2013 and 2017. There were, however, periods of partial revision of these policies - depending on the political orientation of coalition cabinets. I outline briefly here some of the specific developments which occurred between 2007 and 2018.

The fourth Balkenende Cabinet (2007-2010) had shifted colour from CentreRight to Centre-Left. The cabinet returned, to a certain extent, to ideas and structures of the late 1990s. Immigration and integration competences were again split: the first remained at the Ministry of Justice but integration was moved to the Ministry of Housing, under a special (Labour Party) Minister for Housing, Residential Areas and Integration, Ella Vogelaar. So, apart from the new now-national Civic Integration infrastructure embodied in the Civic Integration Law 2007, the local, urban social-cohesion challenge of the 1990s was brought back on the agenda: socio-economic renovation and cohesion policies for vulnerable urban residential quarters. 'Burgerschap' (citizenship) in this context was also redirected towards 'common interests and the common future of all residents' of the vulnerable residential quarters. 
The new minister also partially relaxed the mandatory individual civic integration measures: the unilateral obligatory character was redefined and the interest of newcomers, their future participation, their learning of competences and tools for participation and interaction were stressed. However, the structure of preand post-migration integration courses of an assimilative nature was maintained. Moreover, the comprehensiveness of civic integration was enhanced in the socalled Deltaplan Vogelaar that aimed at the full implementation of the civic integration plans that had suffered thus far from insufficient offers of quality courses, unclear organisation and a problematic division of tasks between the stakeholders involved.

In 2010 this temporary partial relaxation of integration policies was followed by a full swing back in the centre-right minority Rutte I Cabinet that had negotiated the parliamentary support of the anti-immigrant PVV party of Geert Wilders. This 'Integration New Style Revisited' was readily identifiable in the mission statement of the new cabinet (Regeringsverklaring 2010): the government announced that it intended to 'substantially reduce immigration', particularly family migration; 'to secure integration' by increasing the level and requirements of integration courses; to increase the responsibility of the migrants by obliging immigrants to bear the costs of immigration and integration; to couple failure on integration courses with the noncontinuation of residence permits; to make naturalisation more conditional on measured qualifications, participation and integration of the candidate to be awarded; and to stop diversity and affirmative action programmes. A practical target of the government was, furthermore, to bring the costs of civic integration (estimated at about 350 million euros annually) back to zero by the year 2014. The cabinet also went back to combining immigration and integration into one ministry: the Ministry of Justice.

However, the Rutte I Cabinet fell after two years and, in 2012, the Liberal Party (VVD) and the Labour Party (PvdA) came together in a Purple Coalition of the Rutte II Cabinet. The tone on migration and integration issues in the mission statement of this new cabinet was much more moderate and the text much shorter than that of its predecessor of 2010. Nevertheless, the framing was not essentially different:

In the immigration and integration policy we opt for clear and strict requirements for newcomers, for example in the field of income and command of the Dutch language. All admissions procedures will be tightened, but the Netherlands continues to offer room for real refugees. An arrangement will be made for the group of children and young people who have been staying here for years. In this way we pursue a strict but fair immigration policy that takes into account the capacity (draagkracht) of our society.

(Regeringsverklaring 2012)

That the new Purple Coalition government did not, in essence, deviate from the existing policies becomes clear in the third version of the WIN Law on civic 
integration of 2013 (proposed and defended by the Minister for Social Affairs and Employment of the Labour Party, Lodewijk Asscher). The stated aim of new law was 'to reinforce the responsibility of the newcomer for his own civic integration ... he should take the initiative . . choose a course on the market and pay himself'. The main actors in the implementation were DUO (a state agency for loans to students and now also to immigrants to pay for their integration courses) and private educational entrepreneurs on the market who offered courses. Municipalities were only supposed to monitor and sanction new immigrants who did not live up to their obligations. The new law foresaw one central exam for all and shortened the period within which it had to be passed from 3.5 to 3 years. The sanctioning of noncompliance by fines (of 1,250 euros) was foreseen. Loans made by DUO to refugees were acquitted when the exam was passed in time.

It was during this period of the Purple Coalition (2012-2017) that all categories of immigrants (migration for labour, for study, for family reasons and for asylum) increased, particularly in 2014-2016. Most of the attention went on asylumseekers (the 'EU asylum crisis') although the labour and family categories each brought more newcomers to the Netherlands in these three years than the swelling category of asylum-seekers. The 'tightening of admission' promised in the government statement of 2012 had obviously not been successful in restricting immigration.

In 2017, after national elections in which the Labour Party was decimated, a four-party centre-right coalition (VVD, CDA, D66 and CU) was formed in the Rutte III Cabinet. In its official statement, the new coalition committed itself to an 'effective and humane migration and civic integration policy' that would ensure the efficient and fast reception and civic integration of newcomers on the one hand and the fast return of those who were not allowed to stay on the other (see Regeerakkoord 2017). The cabinet also considered it important that the root causes of refugee flows be tackled, that refugees be received in accordance with international conventions and that irregular migration be counteracted.

The most concrete action of the Minister for Social Affairs and Employment, in the cabinet responsible for integration, was his efforts to make the Civic Integration Law of 2013 work. The (implementation of the) law had repeatedly been criticised in various evaluation reports (Algemene Rekenkamer 2017; Nationale Ombudsman 2018; Significant 2018). The shortcomings were many: the privatisation of the civic integration courses, making it a market commodity that was difficult to control; the expectation that the unknowledgeable newcomer should choose an appropriate course in a market that is not transparent; the sidelining of municipalities as directors and monitors of reception and integration; and the resulting low percentage of newcomers who successfully completed their integration courses within the time allotted. The Minister for Social Affairs and Employment admitted that the 2013 WIN Law had not been successful and slightly refined it in 2017. Newcomers were now obliged to learn about core Dutch values and had to sign a declaration that they would uphold them.

More fundamentally, however, the minister announced, in July 2018, that a new civic integration law would be enacted in 2021 (EK 2017-2018, 34 584, 
I). Important elements of the new law would be a better control of the market in course offerings, making the civic integration trajectory more individualised through Personal Integration and Participation Plans (PIP), the improvement of the connection between integration courses and employment, and the bringing back of municipalities as directors and monitors of the civic integration of newcomers.

To sum up these developments in migration and integration policies in the period 2002-2018, we can see that the framing of immigration was stable over the whole period: as before, immigration was not wanted and should be restricted as much as possible. The seven Cabinets of this period all had the same message, albeit that the tone varied somewhat. In this light, it is remarkable that the practice of immigration varied significantly: it was effectively low, with negative net migration in 2003-2006, was back at the 2002 level in 2008 and started to grow from then on. In 2018, a net migration peak of 88,000 was reached.

Integration policy-making underwent a thorough reframing in the first period of 2002-2007: civic integration had become the main element of national policymaking - and in a very specific way. The courses that had been introduced in the late 1980s and 1990s as a toolkit offered to certain immigrants to facilitate their integration were now mandatory courses that aimed to also teach Dutch norms and values and (where possible, as in the case of family migration) to select those immigrants who were the most likely to integrate. In this new framing, the immigrants' responsibility was enlarged: not only should the immigrant accept and adapt to the norms and values of Dutch society but the financial costs of immigration in general and of integration courses specifically were also increasingly laid on his or her shoulders. This new framing became standard - i.e. it formed the starting point of both centre-right and centre-left coalitions in the period after 2007. What made centre-left coalitions distinct from those of the centre-right was that the former brought other elements of integration to the table in addition to civic integration. This difference was consistently expressed in the institutional embedding of integration policies: centre-right coalitions always brought immigration and integration together within one ministry (and under one minister), that of Justice (and Security). Centre-left coalitions (and the present coalition) wanted to keep immigration (preferably at the Ministry of Justice) separate, in principle, from integration by choosing the Ministries for Housing (2007-2010) or Social Affairs and Employment (2012-2017).

\section{Conclusions}

In this chapter we have seen how the immigration policies of the Netherlands are related to integration policies. We have examined immigration and integration policies and their changes in time at two levels: the framing and aims of policies as formulated in governmental documents and the embodiment of policies in regulations, organisations and budgets. Such an analysis leads us to distinguish five periods in the postwar Netherlands in which the relation between migration and integration was framed in different ways. 


\section{0}

A comparative analysis of these periods shows that the framing of immigration policies, on the one hand, was relatively consistent over time: the mantra in all five periods was 'The Netherlands is not an immigration country' and admission policies should be restrictive and selective for foreigners (newcomers from former colonial territories were selected on their citizenship and not defined as immigrants). The results of such policies and measures of restrictiveness, however, varied significantly: since the beginning of the 1960s there were consistently positive net migration figures, with only two brief exceptions in 1966/67 and 2003-2006. This contradiction between the aims of immigration policies and their outcomes made the Netherlands an 'unwilling immigration country', with 23 per cent of its population having a migration background - i.e. born or having parents born abroad - in 2018.

Integration policies, on the other hand, showed major frameshifts. In the first two periods (1945-1960 and 1960-1980) there were integration and absorption policies for newcomers from (ex-)colonies who were citizens but, for all other foreign newcomers, the non-integration and assumed temporariness of stay dominated policies. In the third period (1980-1994) the Ethnic Minorities Policy brought about a fundamental frameshift: for those newcomers - whether citizens or not - who had found a place in Dutch society but in the lower strata, a policy of structural integration and socio-cultural emancipation aimed to prevent the formation of an ethnic underclass and to bring about social mobility and societal acceptance. The next period of neoliberal citizenship policies (1994-2002) redefined integration and integration policies as offering opportunities to immigrants to promote their structural integration and adaptation to Dutch society - first and foremost as a duty for the immigrant. Finally, under conditions of hyper-politicisation, integration policies were increasingly narrowed down to mandatory civic integration courses to teach immigrants how to fit into Dutch society. On these courses they would learn about the language, structure, norms and values of their new society (and subscribe to the latter).

The relation between immigration and integration policies changed in each period. In the first two periods (1945-1980) the immigration of noncitizens was defined as temporary; thus, integration should be avoided and return promoted (when former colonial citizens came into the country, however, absorption and assimilation were the course of action). In the third period (1980-1994) the integration of those who had arrived in spite of restrictive immigration policies should be enhanced in order to avoid a permanent ethnic underclass in Dutch society. This new framing of integration in the Ethnic Minorities Policy did not, in principle, change the undesirability of immigration and the restrictiveness of immigration policies. However, in practice the new framing did change the practice for certain categories of immigrant - the importance given to the completeness of families for the integration trajectory was a particularly strong argument for more lenient family migration practices in the 1980s.

Since the early 1990s, the 'failed integration of immigrants' argument has been used to reinforce the restrictiveness of admission policies in general - it especially reversed the argument in favour of family migration in EMP policies into one 
against it in integration policies of the 1990s. New family members and particularly new marriage partners were now seen as hindrances to integration. Thus, family migration policies would became stricter in the fourth period (1994-2002).

Since 2002, a more systemic connection between immigration and integration has developed. Not only do policy memoranda explicitly address the need to restrict immigration in order not to endanger the 'absorption capacity' of Dutch society (Ministerie van Binnenlandse Zaken 2001) but tougher integration policies have also increasingly become a tool for restricting immigration. The new pre- and post-migration civic integration programmes described in this chapter have become a way for the Dutch government to promote the integration of newcomers as well as to discourage further immigration. In so doing, they simultaneously function as a mechanism through which to select those migrants who could prove beneficial for the Dutch economy and society.

\section{Notes}

1 I define the integration process as the two-sided settlement process of newcomers in a new society that has three dimensions in which they become (or not) an 'accepted part of society'. The three dimensions can be studied separately: the legal/political dimension (which concerns the legal status of the migrant and access to political decision-making), the socio-economic dimension (which can be measured by equal opportunities and participation in hard sectors of work and income, housing, education and health care) and the ethnic/cultural/religious dimension - where it concerns the (non-)acceptance of world views/religion, culture and ethno-cultural identity (see Penninx and Garcés-Mascareñas 2016: 14-19). Integration policies aim to steer the integration processes of immigrants towards an outcome desired and formulated by politics. In the analysis of the content of integration policies it is important to look at what they aim to achieve and what is done in each of these dimensions.

2 For a more extensive treatment, see Penninx and Garcés-Mascareñas (2016: 11-30).

3 For the most comprehensive analysis of framing and frameshifts in Dutch integration policies, see Scholten (2011).

4 Some important historical overview studies using contemporary documents and sources for emigration in this period are: Beijer and Oudegeest (1952); Faassen (2014); Hofstede (1964); Lucassen and Lucassen (2018); Obdeijn and Schrover (2008). On immigration, see: Amersfoort (1971, 1982); Kraak et al. (1957); Smeets and Steijlen (2006); Surie (1971).

5 'The Dutch government was of the opinion that the Indonesian Dutch, in view of the altered conditions, should desist and orient themselves to the new state of Indonesia' (Amersfoort 1982: 83). See also Kraak et al. (1957).

6 Important historical overview studies using contemporary documents and sources are Amersfoort (1971); Bartels (1989); Ministerie van Binnenlandse Zaken (1978); Smeets and Steijlen (2006).

7 The term was coined by Groenendijk (1981).

8 For a comprehensive account of labour migration in the Netherlands, 1945-2006, see Lange (2007).

9 For a detailed analysis, see Amersfoort and Surie (1987) and Amersfoort and Niekerk (2006).

10 The independence of Suriname was seen by many Dutch politicians as a means to stop immigration from the country. However, the approaching independence prompted a new wave of last-chance migration to the Netherlands. 
11 For key texts on how 'maintaining culture and identity' should relate to 'developing and adapting culture and identity to the new society' see Ministerie van Binnenlandse Zaken (1981: $36 \mathrm{ff}, 1983: 107 \mathrm{ff})$.

12 These courses are known in Dutch as inburgeringscursussen. The word 'inburgering' contains the word 'burger' (meaning 'citizen'); however, its denotation is not that of naturalisation (i.e. becoming a national citizen) as much as that of becoming a wellinformed and active participant in society. That is why I prefer to use the term 'civic integration courses' rather than 'citizenship programmes'.

13 The meaning depends on the translation of the Dutch word 'drama' in the title of the article, 'Het multiculturele drama'.

14 Interview published in the newspaper De Volkskrant, 2 November 2001.

15 See comments on the report of the Blok Commission in Parliament in TK (Lower House) 2003-2004, nr. 63, pp. 4093-4150 (6 April 2004).

16 The Balkenende I Cabinet was a short-lived coalition of Christian Democrats, Liberals and the extreme-right LPF; LPF-member Nawijn was the Minister for Alien Affairs and Integration. The Balkenende II Cabinet, a coalition in which the LPF was substituted by the progressive liberals of D66 followed in 2003. VVD-member Rita Verdonk became Minister for Aliens Affairs and Integration (until 2007).

17 That responsibility also had its financial aspects: all costs of admission and immigration for the state should be borne by the immigrants themselves. This principle was introduced - without much debate - following implementation of New Style integration policy. Immigrants had to pay sums of money for visas and residence permits - as well as their renewal - that were previously unheard of.

18 The principles of the new policies are formulated and developed in the policy documents the Hoofdlijnenakkoord Balkenende II of 16 May 2003 (TK 2002-2003, 03 28637, No. 19) and the Contourennota Herziening van het Inburgeringsstelsel (TK 2003-2004, 29543, No. 1).

\section{References}

Algemene Rekenkamer (2017) Inburgering. Eerste Resultaten van de Wet Inburgering 2013 (Civic Integration. First Results of the WIN Law 2013). The Hague: Algemene Rekenkamer (General Auditor).

Amersfoort, H. van (1971) 'De Molukkers (The Moluccans)', in Verwey-Jonker, H. (ed.) Allochtonen in Nederland (Allochthonous Persons in the Netherlands). The Hague: Staatsuitgeverij, pp. 111-144.

Amersfoort, H. van (1982) Immigration and the Formation of Minority Groups: The Dutch Experience 1945-1975. Cambridge: Cambridge University Press.

Amersfoort, H. van and Surie, B. (1987) 'Immigratieland tegen wil en dank; Nederland 1970-1985' ('A willy-nilly immigration country'), in van der Wusten, H. (ed.) Postmoderne Aardrijkskunde. De Sociografische Traditie Voortgezet. Muiderberg: Coutinho, pp. 180-194.

Amersfoort, H. van and van Niekerk, M. (2006) 'Immigration as a colonial inheritance: Post-colonial immigrants in the Netherlands, 1945-2002', Journal of Ethnic and Migration Studies, 32(3): 323-346.

AWV (1969) Buitenlandse Arbeiders: Een Economische Verkenning (Foreign Workers: An Economic Exploration). The Hague: Algemene Werkgevers Vereniging (General Employers Association) Afdeling Research.

Bartels, D. (1989) Moluccans in Exile: A Struggle for Ethnic Survival. Socialization, Identity Formation and Emancipation among an East-Indonesian Minority in the Netherlands. Leiden: COMT/IWM. 
Beijer, G. and Oudegeest, J.J. (1952) Some Aspects of Migration Problems in the Netherlands. The Hague: Martinus Nijhoff.

Beune, H. and Hessels, J.A. (1983) Minderheid: Minder Recht? (Minority: Fewer Rights?). The Hague: Staatsuitgeverij.

Blok Commission (2004) Bruggen Bouwen. Eindrapport van de Tijdelijke Parlementaire Onderzoekscommissie Integratiebeleid. (Building Bridges. Final Report of the Temporary Parliamentary Inquiry Committee for Integration Policy). The Hague: SDU.

Böcker, A. and Clermonts, L. (1995) Poortwachters van de Nederlandse Arbeidsmarkt (Gatekeepers of the Dutch Labour Market). Nijmegen: Katholieke Universiteit Nijmegen, Instituut voor Rechtssociologie.

Bolkestein, F. (1991) Address to the Liberal International Conference at Luzern, Friday 6 September. The Hague: VVD Tweede-Kamerfractie.

Eldering, L. (1989) 'Ethnic minority children in Dutch schools: Underachievement and its explanations', in Eldering, L. and Kloprogge, J. (eds) Different Cultures, Same School: Ethnic Minority Children in Europe. Amsterdam/Lisse: Swets \& Zeitlinger, pp. 107-136.

Entzinger, H.B. (1975) 'Nederland Immigratieland? Enkele overwegingen bij het overheidsbeleid inzake allochtone minderheden' ('The Netherlands, an immigration country? Some considerations for policy towards foreign minorities'), Beleid en Maatschappij, 2(12): 326-336.

Entzinger, H.B. (1985) 'The Netherlands', in Hammar, T. (ed.) European Immigration Policy: A Comparative Study. Cambridge: Cambridge University Press, pp. 50-88.

Entzinger, H.B. (2003) 'The rise and fall of multiculturalism: The case of the Netherlands', in Joppke, C. and Morawska, E. (eds) Toward Assimilation and Citizenship: Immigrants in Liberal Nation-States. Hampshire: Palgrave Macmillan, pp. 59-86.

Faassen, M. van (2014) Polder en Emigratie. Het Nederlandse Emigratiebestel in Internationaal Perspectief 1945-1967 (Polder and Emigration. The Dutch Emigration System in International Perspective). Groningen: University of Groningen, unpublished $\mathrm{PhD}$ thesis.

Groenendijk, K. (1981) 'Minderhedenbeleid in een onwillig immigratieland' ('Minorities policy in an unwilling immigration country'), Ars Aequi, 30(10): 531-547.

Hofstede, B.P. (1964) Thwarted Exodus: Post-War Overseas Migration from the Netherlands. The Hague: Martinus Nijhoff.

Kraak, J.H., Ploeger, P. and Kho, F.O.J. (1957) De Repatriëring uit Indonesië: Een Onderzoek naar de Integratie van de Gerepatriëerden in de Nederlandse Samenleving (Repatriation from Indonesia: An Inquiry into the Integration of Repatriates into Dutch Society). The Hague: Staatsuitgeverij.

Lange, T. de (2004) 'Tripartite agreements on labour migration. The case of the health-care sector in the Netherlands', IMIS-Beiträge, 24: 137-149.

Lange, T. de (2007) Staat, Markt en Migrant: De Regulering van Arbeidsmigratie naar Nederland 1945-2006 (State, Market and Migrant: The Regulation of Labour Migration into the Netherlands 1945-2006). The Hague: Boom Juridische Uitgevers.

Lucassen, J. and Penninx, R. (1997) Newcomers, Immigrants and their Descendants in the Netherlands 1550-1995. Amsterdam: Het Spinhuis.

Lucassen, L. and Lucassen, J. (2018) Vijf Eeuwen Migratie. Een Verhaal van Winnaars en Verliezers (Five Centuries of Migration. A Story of Winners and Losers). Amsterdam/ Antwerp: Atlas Contact.

Ministerie van Binnenlandse Zaken (1978) De Problematiek van de Molukse Minderheid in Nederland (The Issue of the Moluccan Minority in the Netherlands). The Hague: Staatsuitgeverij (Tweede Kamer 1977-1978, 14915, Nos. 1-2). 


\section{Rinus Penninx}

Ministerie van Binnenlandse Zaken (1980) Regeringsreactie op het Rapport 'Etnische Minderheden'van de Wetenschappelijke Raad voor het Regeringsbeleid (Reaction of the Government to the Report 'Ethnic Minorities' of the Scientific Council for Government Policy). The Hague: Ministerie van Binnenlandse Zaken.

Ministerie van Binnenlandse Zaken (1981) Ontwerp-Minderhedennota (Draft Minorities Bill). The Hague: Ministerie van Binnenlandse Zaken.

Ministerie van Binnenlandse Zaken (1983) Minderhedennota (Minorities Bill). The Hague: Staatsuitgeverij (Tweede Kamer 1982-83, 16102, No. 21).

Ministerie van Binnenlandse Zaken (1994) Contourennota Integratiebeleid Etnische Minderheden (Contours Integration Policy for Ethnic Minorities). The Hague: Ministerie van Binnenlandse Zaken.

Ministerie van Binnenlandse Zaken (2001) Integratie in het Perspectief van Immigratie (Integration from the Perspective of Immigration). The Hague: Ministerie van Binnenlandse Zaken (also in Tweede Kamer, 2001-2002, 28198, No. 1).

Ministerie van Justitie (2003) Integratiebeleid Nieuwe Stijl (Integration Policy New Style). The Hague: Ministerie van Justitie (Tweede Kamer, 2003-2004, 29203, No. 1).

Ministerie van Sociale Zaken en Werkgelegenheid (1970) Nota Buitenlandse Werknemers (Memorandum on Foreign Workers). The Hague: Ministerie van Sociale Zaken en Werkgelegenheid (Tweede Kamer, 1969-1970, 10504, 14 January).

Ministerie van Sociale Zaken en Werkgelegenheid (1974) Memorie van Antwoord op het Voorlopig Verslag op de Nota Buitenlandse Werknemers (Memorandum of Reply to the Preliminary Report on the Memorandum on Foreign Workers). The Hague: Ministerie van Sociale Zaken en Werkgelegenheid (Tweede Kamer, 1973-1974, 10504, No. 9).

Muus, P. (1990) Migration, Minorities and Policy in the Netherlands. Recent Trends and Developments. Report for the Continuous Reporting System on Migration (SOPEMI). Amsterdam: CEMIO.

Muus, P. (1997) 'Shifting borders: The inclusion and exclusion of refugees and asylum seekers in the Netherlands', in Muus, P. (ed.) Exclusion and Inclusion of Refugees in Contemporary Europe. Utrecht: ERCOMER, pp. 78-90.

Nationale Ombudsman (2018) Een Valse Start. Een Onderzoek naar Behoorlijke Inburgering (A False Start. Research into Decent Civic Integration. Rapport 2018-65. The Hague: Nationale Ombudsman.

Obdeijn, H. and Schrover, M. (2008) Komen en Gaan. Immigratie en Emigratie in Nederland vanaf 1550 (Coming and Going. Immigration and Emigration in the Netherlands since 1550). Amsterdam: Bert Bakker.

Penninx, R. (1979) 'Towards an overall ethnic minorities policy', in Scientific Council for Government Policy (ed.) Ethnic Minorities. Report No. 17. The Hague: State Publishers.

Penninx, R. (2006) 'After the Fortuyn and Van Gogh murders: Is the Dutch integration model in disarray?', in Delorenzi, S. (ed.) Going Places. Neighbourhood, Ethnicity and Social Mobility. London: Institute for Public Policy Research, pp. 127-138.

Penninx, R. and Garcés-Mascareñas, B. (2016) 'The concept of integration as an analytical tool and as a policy concept', in Garcés-Mascareñas, B. and Penninx, R. (eds) Integration Processes and Policies in Europe. Contexts, Levels, Actors. Dordrecht: Springer, pp. 11-29.

Pluymen, M. (2004) 'Exclusion from social benefits as an instrument of migration policy in the Netherlands', IMIS-Beiträge, 24: 75-87.

Praag, C.S. van (1973) 'Het overheidsbeleid inzake allochtone groepen' ('Official policy towards foreign groups'), in Verwey-Jonker, H. (ed.) Allochtonen in Nederland (Allochthonous Persons in the Netherlands). The Hague: Staatsuitgeverij, pp. 21-46. 
Prins, B. (2002) 'Het lef om taboes te doorbreken. Nieuw realisme in het Nederlandse discours over multiculturalisme' ('The courage to debunk taboos. New realism in the Dutch discourse on multiculturalism'), Migrantenstudies, 18(4): 241-254.

Regeerakkoord (2017) Vertrouwen in de Toekomst. Regeerakkoord 2017-2021 (Trust in the Future. Government Agreement 2017-2021): Available at www.kabinetsformatie2017. $\mathrm{nl} /$ documenten/publicaties/2017/10/10/regeerakkoord-vertrouwen-in-de-toekomst (accessed 13 August 2019).

Regeringsverklaring (2010) De integrale regeringsverklaring, uitgesproken door premier Mark Rutte op dinsdag 26 oktober 2010 (The Government Declaration Spoken by Premier Rutte on Tuesday, October 26, 2010). Available at www.volkskrant.nl/vk/nl/3598/ Binnenland/article/detail/1039867/2010/10/26/Regeringsverklaring-Mark-Rutte.dhtml (accessed 13 August 2019).

Regeringsverklaring (2012) De volledige regeringsverklaring van het tweede cabinet-Rutte (The Government Declaration of the Second Cabinet-Rutte), 3 November. Available at www.volkskrant.nl/nieuws-achtergrond/de-volledige-regeringsverklaring-van-hettweede-kabinet-rutte bc61f607/ (accessed 13 August 2019).

Scheffer, P. (2000) 'Het Multiculturele Drama' ('The multicultural tragedy'), NRC Handelsblad, 29 January.

Scholten, P.W.A. (2011) Framing Immigrant Integration: Dutch Research-Policy Dialogues in Comparative Perspective. Amsterdam: Amsterdam University Press.

Scientific Council for Government Policy (1979) Ethnic Minorities. The Hague: Staatsuitgeverij.

Scientific Council for Government Policy (1989) Immigrant Policy. The Hague: SDU.

Significant (2010) Evaluatierapport Inburgering in Nederland (Evaluation of Civic Integration Courses in the Netherlands). Barneveld: Significant.

Significant (2018) Inburgering. Systeemwereld versus Leefwereld: Evaluatie Wet Inburgering 2013 (Civic Integration Courses. System World versus Lived World: Evaluation of the WIN-Law 2013). Barneveld: Significant.

Smeets, H. and Steijlen, F. (2006) In Nederland Gebleven. De Geschiedenis van Molukkers 1951-2006 (Stuck in the Netherlands. The History of Moluccans 1951-2006). Amsterdam/Utrecht: Bert Bakker/Moluks Historisch Museum.

Staay, A.J. van der (1967) 'Het probleem van de buitenlandse arbeiders en het probleem van het bijbehorende overheidsbeleid' ('The problem of foreign workers and the problem of the appropriate policies'), in Wentholt, R. (ed.) Buitenlandse Arbeiders in Nederland (Foreign Workers in the Netherlands). Leiden: Spruyt, Van Mantgem en De Does, pp. $57-80$.

Staay, A.J. van der (1973) 'Nederland, buitenlandse arbeiders en het welzijn' ('The Netherlands: Foreign workers and welfare'), in Verwey-Jonker, H. (ed.) Allochtonen in Nederland (Allochthonous Persons in the Netherlands). The Hague: Staatsuitgeverij, pp. 191-218.

Surie, H.G. (1971) 'De gerepatrieerden' ('The repatriates'), in Verwey-Jonker, H. (ed.) Allochtonen in Nederland (Allochthonous Persons in the Netherlands). The Hague: Staatsuitgeverij, pp. 47-110.

Vasta, E. (2006) From Ethnic Minorities to Majority Policy: Changing Identities and the Shift to Assimilationism in the Netherlands. Oxford: COMPAS, WP-06-26.

Walsum, S. van (2004) 'The dynamics of emancipation and exclusion. Changing family norms and Dutch family migration policies', IMIS-Beiträge, 24: 119-128. 